\title{
Implementasi Metode Uswah Hasanah pada Pembelajaran Jarak Jauh di MTs Al Azhar Tembongraja Salem Brebes
}

\author{
Agus Samsudin*, Andewi Suhartini \& Nurwadjah Ahmad EQ \\ Pascasarjana UIN Sunan Gunung Djati Bandung \\ *320021003@student.uinsgd.ac.id
}

\begin{abstract}
This study aims to find out how the implementation of the Uswah Hasanah method during Distance Learning because of the COVID-19 pandemic at MTs Al Azhar Tembongraja, Salem, Brebes. This research is qualitative research with an analytical descriptive method. Data collection techniques were carried out through interviews and literature. The subjects in this study were the principal, deputy head of the curriculum, deputy head of students, some teachers, and some students. Data analysis was carried out by selecting the data obtained and then collected for analysis and conclusions drawn. The findings in this study are that the implementation of the Uswah Hasanah Method during the PJJ of the COVID-19 pandemic, educators experienced various difficulties because there was almost no face-to-face during learning. Although there is no face-to-face, educators use social media in applying the uswah method, including by saying greetings in each learning session, being on time in starting the lesson schedule, greeting students, asking how students are, and praying for them to always be given health, giving rewards with words of congratulations for outstanding students and other motivational words and so on through social media groups. Keywords: distance learning, Uswah hasanah, COVID-19 Pandemic
\end{abstract}

\begin{abstract}
Abstrak
Penelitian ini bertujuan untuk mengetahui bagaimana implementasi metode uswah hasanah Pembelajaran Jarak Jauh (PJJ) pada masa pandemi COVID-19 di MTs Al Azhar Tembongraja, Salem, Brebes. Penelitian ini merupakan penelitian kualitatif dengan metode deskriptif analitik. Teknik pengumpulan data dilakukan melalui wawancara dan kepustakaan. Subjek dalam penelitian ini ialah kepala sekolah, waka kurikulum, waka kesiswaan, sebagian guru dan sebagian peserta didik. Analisis data dilakukan dengan memilih data yang diperoleh selanjutnya dikumpulkan untuk dianalisis dan diambil kesimpulan. Hasil temuan dalam penelitian ini adalah bahwa implementasi metode uswah hasanah dimasa PJJ pandemi COVID-19 ini pendidik mengalami berbagai kesulitan karena hampir tidak adanya tatap muka selama pembelajaran. Meskipun tidak ada tatap muka, pendidik memanfaatkan media sosial dalam menerapkan metode uswah hasanah di antaranya dengan cara mendahului mengucapkan salam dalam setiap sesi pembelajaran, tepat waktu dalam memulai jadwal pelajaran, menyapa peserta didik, menanyakan kabar peserta didik dan mendoakannya agar selalu di beri kesehatan, memberikan reward dengan kata-kata selamat bagi siswa yang berprestasi serta kata-kata motivasi lainnya dan lain sebagainya melalui grup media sosial.
\end{abstract}

Kata Kunci: PJJ, Uswah hasanah, Pandemi COVID-19 


\section{Pendahuluan}

Samsudin, A., Suhartini, A., \& Ahmad EQ, N. (2021).

Bagi manusia, secara fitrah, keteladanan merupakan kebutuhan yang mendasar. Sebab, manusia diberi fitrah oleh Allah untuk mencari uswah hasanah atau suri teladan bagi kehidupan dan menjadi pedoman bagi mereka, menunjukkan jalan kebenaran dan menjadi contoh hidup yang menjelaskan kepada mereka bagaimana seharusnya melaksanakan syariat Allah. Karenanya untuk merealisasikan risalah-Nya di muka bumi ini, Allah mengutus para rasul-Nya untuk menjelaskan kepada manusia syariat yang diturunkan Allah kepada mereka (Rosyadi, 2014).

Bagi umat Islam, bahkan bagi seluruh manusia, Rasulullah merupakan teladan yang paling sempurna. Dengan sifatnya yang pemaaf, lembut, penyayang dan sabar, orang yang tadinya tidak suka dan benci kepada beliau justru malah menyukai dan ingin menjadi sahabatnya. Selain itu juga dengan keteladanannya, Rasulullah dapat membimbing dan mendidik para sahabatnya. Metode keteladanan ini termasuk metode yang tertua dan tergolong paling sulit dan mahal. Dengan metode ini, pendidikan agama disampaikan melalui contoh teladanan yang baik dari pendidiknya, sebagaimana telah dilakukan oleh para Nabi terdahulu (Patoni, 2004).

Setiap anak mula-mula meniru kedua orang tuanya. Hampir semua perkataan dan tingkah lalu orang tua ditiru oleh anaknya. Oleh karena itu, orang tua harus menjadi dan memberikan teladan yang baik bagi anak-anaknya. Membaca basmalah sebelum makan misalnya, salat berjamaah dan lain sebagainya. Akan tetapi setelah anak masuk ke jenjang pendidikan, anak mulai akan meneladani apa yang dilakukan oleh gurunya. Oleh karenanya guru perlu memberikan keteladanan yang baik kepada peserta didiknya agar penanaman karakter baik menjadi lebih efektif dan efisien.

Guru sebagai fasilitator dalam kegiatan belajar mengajar dapat menciptakan suasana yang menggairahkan bagi anak didiknya. Guru juga mempunyai peranan penting dalam mengembangkan moral agama anak dengan cara: memberikan contoh peserta didik untuk berperilaku sopan, seperti memberi ucapan salam tatkala masuk kelas dan bertemu dengan guru, mencium tangan kedua orang tua ketika berjabat tangan, berbagi sesuatu dengan teman, bekerja sama dalam kebaikan, memiliki sikap pemaaf, maka dengan sendirinya perilaku seperti itu akan menjadi suatu kebiasaan mereka sehari-hari (Hidayatul, 2016).

Guru moral yang ideal ialah mereka yang bisa menempatkan dirinya sebagai fasilitator, pemimpin, orang tua dan bahkan tempat menyandarkan kepercayaan, serta membantu orang lain dalam melakukan refleksi (Machsunah \& Chayatun, 2017).

Selanjutnya tugas guru juga tidak hanya sebatas melahirkan peserta didik yang sukses pada bidang akademik saja, akan tetapi juga bertanggung jawab mencetak atau membentuk perilaku dan akhlak peserta didik ke arah yang lebih baik. Guru harus memiliki sikap dinamis, senantiasa menggali dan menimba ilmu pengetahuan yang baru 
Implementasi Metode Uswah Hasanah pada Pembelajaran Jarak Jauh...

melalui pembelajaran dan pengalaman serta menyesuaikan diri dengan perkembangan zaman yang senantiasa berubah.

Pendidikan keteladanan bukan hanya memberikan pemahaman secara verbal, bagaimana konsep-konsep tentang akhlak baik dan buruk, tetapi memberikan contoh secara langsung kepada mereka. Karena pada umumnya anak cenderung meneladani, meniru guru atau pendidiknya. Hal ini memang secara psikologis anak memang sering meniru, tidak saja yang baik, bahkan terkadang yang jelek juga mereka tiru.

Uswah hasanah (keteladanan) dapat ditunjukkan dalam perilaku dan sikap pendidik dan seluruh komponen sekolah dalam memberikan contoh tindakan-tindakan yang baik sehingga diharapkan menjadi panutan bagi peserta didik untuk mencontohnya. Apabila pendidik dan seluruh komponen sekolah menghendaki peserta didiknya mempunyai perilaku dan sikap yang sesuai dengan nilai-nilai agama, maka mendemonstrasikan berbagai contoh teladan merupakan langkah awal pembiasaan. Pendidik dan seluruh komponen sekolah merupakan orang yang harus pertama memberikan contoh bagaimana berperilaku dan bersikap sesuai dengan nilai-nilai tersebut. Misalnya datang ke sekolah tepat waktu, berpakaian rapi, bekerja keras, berkata sopan, perhatian terhadap peserta didik, berkata jujur, menjaga kebersihan dan lain sebagainya. Keteladanan dalam pendidikan karakter dapat dilakukan melalui pengintegrasian ke dalam kegiatan sehari-hari satuan pendidikan formal dan nonformal dan berwujud kegiatan rutin atau kegiatan spontan.

Dari uraian-uraian di atas bisa dipahami bahwa pendidikan tidak akan sukses melainkan jika disertai dengan pemberian contoh atau teladan yang baik dan nyata. Maka, sudah seharusnya orang tua atau guru menunjukkan perilaku yang baik di mana pun berada dan bagaimanapun keadaannya, sebab tingkah lakunya akan menjadi teladan dan tolok ukur bagi murid-muridnya.

Pendidikan merupakan tujuan hidup yang harus ditempuh dengan perjuangan yang tidak mudah. Setiap pendidikan yang ditempuh seseorang, diharapkan dapat memberikan sebuah kehidupan yang berharga di masa depan. Namun, sejak pandemi COVID-19 melanda dunia termasuk Indonesia, pendidikan di Indonesia pun beralih melalui daring (online). Hampir semua jenjang mulai dari RA/TK sampai Perguruan Tinggi, pembelajarannya dilaksanakan melalui platform belajar online atau Pembelajaran Jarak Jauh (PJJ). Hal itu dilakukan demi keselamatan bersama dan karena adanya Surat Edaran Nomor 4 Tahun 2020 Menteri Pendidikan dan Kebudayaan, Nadiem Anwar Makarim, tentang Pelaksanaan Pendidikan Dalam Masa Darurat Corona Virus Disease (COVID-19).

Dalam catatan sejarah, sebenarnya istilah pendidikan jarak jauh (PJJ) telah dikenal sejak sekitar tahun 1720-an dalam bentuk korespondensi dengan menggunakan bahanbahan belajar tercetak yang disampaikan kepada peserta didik menggunakan jasa 
layanan pos (Purwanto, 2009). Menurut Joseph McCall, Pembelajaran Jarak Jauh (PJJ) dimulai sejak terjadinya Perang Dunia kedua. Ketika Perang Dunia kedua berlangsung, pelajar atau peserta didik mengalami kesulitan dalam melakukan perjalanan ke sekolah sebagai tempat mereka belajar guna mengikuti kegiatan pembelajaran secara teratur. Dalam menghadapi keadaan seperti itu, karena pertemuan tatap muka tidak memungkinkan untuk dilaksanakan, maka pembelajaran jarak jauh dalam bentuk korespondensi dengan menggunakan layanan merupakan pembelajaran jarak jauh yang pertama kali dilakukan. Bahan-bahan belajar yang akan digunakan atau dipelajari, dikemas ke dalam bentuk tertulis atau rekaman (McCall, 2004).

Pengertian pendidikan jarak jauh (distance learning) menurut Nursel Selver Ruzgar (2004) yang merujuk pada pemikiran Desmond Keegan ditandai dengan adanya unsurunsur, seperti:

1) the separation of teacher and learner which distinguishes it from face-to face lecturing, 2) the influence of an educational organization which distinguishes it from private study, 3) the use of technical media, usually print, to unite teacher and learner and carry the educational content, 4) the provision of a two-way communication so that the student may benefit from or even initiate dialogue, 5) the possibility of occasional meetings for both didactic and socialization purposes, and 6) the participation in an industrialized form of education, which if accepted, contains the genus of radical separation of distance education from other forms.

Berdasarkan pemikiran Ruzgar dan berbagai ahli lainnya, karakteristik pendidikan jarak jauh adalah sebagai berikut: Keterpisahan ruang antara pendidik dan peserta didik dalam pembelajaran dan hal inilah yang membedakan dengan pembelajaran tatap muka, penggunaan media yang lebih menonjol dibandingkan dengan pembelajaran tatap muka, materi pelajaran dirancang dan dikemas secara khusus dalam bentuk bahan belajar mandiri, baik yang berupa media cetak maupun dalam bentuk media rekaman sehingga dapat dipelajari secara mandiri oleh peserta didik baik secara perseorangan maupun dalam kelompok kecil, komunikasi antara pendidik dan peserta didik pada umumnya dilakukan dengan menggunakan media seperti: telepon, layanan pesan singkat (SMS), media sosial, layanan virtual, email apabila ada materi pelajaran yang masih sulit dipahami atau ada hal-hal penting lainnya yang berkaitan dengan pelajaran yang membutuhkan solusi atau pemecahan, sebagian besar waktu belajar peserta didik digunakan untuk belajar mandiri, baik secara perseorangan maupun dalam kelompok kecil dan beberapa lembaga penyelenggara pendidikan jarak jauh menyediakan layanan belajar tutorial, baik yang bersifat tatap muka maupun melalui pemanfaatan media elektronik atau jaringan.

Terkait belajar dari rumah, Mendikbud menekankan bahwa PJJ dilaksanakan guna memberikan pengalaman belajar yang bermakna bagi siswa, tanpa terbebani tuntutan menuntaskan seluruh capaian kurikulum untuk kenaikan kelas maupun kelulusan. Pembelajaran lebih di tekankan kepada memberikan peningkatan pemahaman siswa 
terhadap virus korona dan wabah COVID-19. Adapun aktivitas dan tugas pembelajaran dapat bervariasi antar peserta didik yang disesuaikan dengan bakat dan minat serta kondisi masing-masing, termasuk dalam hal kesenjangan akses atau fasilitas belajar di rumah. Meskipun pembelajaran beralih menjadi pembelajaran dari rumah, bukan berarti guru atau pendidik hanya memberikan tugas rutin saja kepada peserta didik, tetapi juga harus ikut berinteraksi dan berkomunikasi untuk membantu peserta didik dalam mengerjakan tugas-tugas mereka. Guru tetap perlu berkomunikasi dan berinteraksi dengan siswanya meskipun tidak dalam ruang kelas.

Penerapan metode uswah hasanah di era pandemi seperti ini justru menjadi hal yang sangat penting mengingat kondisi seperti ini memaksa guru dan peserta didik harus berinteraksi hanya lewat dunia maya. Meskipun demikian, guru harus menjadi teladan bagi para siswanya. Situasi seperti ini menjadi dilema dan tantangan tersendiri bagi pendidik dan para peserta didik. Di satu sisi kondisi seperti ini menjadikan guru lebih mengenal dunia teknologi yang semakin maju dan dipaksa harus melaksanakan PJJ guna memutus mata rantai penyebaran COVID-19, tetapi di sisi lain timbul kebosanan karena berbagai keterbatasan yang ada. Lebih menghawatirkan lagi, posisi guru yang harusnya menjadi suri teladan dalam setiap perkataan dan perbuatannya menjadi sangat terbatas. Meskipun pembelajaran dilaksanakan secara tatap muka dengan memakai protokol kesehatan secara ketat tetap meningkatkan risiko terpapar COVID- 19.

Penelitian mengenai implementasi metode uswah hasanah memang sudah dilakukan oleh beberapa peneliti. Seperti penelitian yang dilakukan oleh Aisyah Ma'awiyah berjudul Metode uswah hasanah Dalam Pembentuk Karakter Usia MI/SD. Penelitian tersebut menyimpulkan bahwa karakter (Akhlak) anak yang baik dapat terbentuk dengan memberi contoh teladan oleh orang tua dengan memperkenalkan agama, mengembangkan sikap disiplin, mengembangkan sikap tanggung jawab, jujur, bekerja keras, kesopanan, budi pekerti dan tingkah laku yang baik sejak usia dini yaitu usia MI/SD, sehingga anak cenderung memperhatikan tingkah laku dan meniru orang tua/ guru sehari-hari. Namun penelitian tersebut dilakukan sebelum masa pandemi (Ma'awiyah, 2017). Selanjutnya penelitian yang dilakukan oleh Siti Maesaroh dkk. yang menyimpulkan bahwa metode pembelajaran Uswah Hasanah terbukti mampu memberikan kontribusi yang lebih besar dibandingkan menggunakan metode pembelajaran konvensional. Metode Uswah Hasanah efektif untuk meningkatkan akhlakul karimah siswa, karena peningkatan nilai yang didapat signifikan (Maesaroh, Abdussalam, \& Surahman, 2019). Ada salah satu penelitian dimasa pandemi yang dilakukan oleh Awaludin Faj (Faj, 2021) tentang penerapan metode pembelajaran suri teladan di era pandemi. Penelitian tersebut menyimpulkan bahwa kelebihan metode keteladanan memberikan kemudahan kepada pendidik dalam melakukan evaluasi terhadap hasil dari proses belajar mengajar yang dijalankannya. Sedangkan kekurangannya jika dalam proses belajar mengajar figur yang diteladani tidak baik, maka 
Samsudin, A., Suhartini, A., \& Ahmad EQ, N. (2021). peserta didik cenderung mengikuti hal-hal yang tidak baik tersebut pula. hanya saja, penelitian tersebut menggunakan metode literatur (library research) tanpa melibatkan responden sebagai narasumber dan tentu saja tidak memiliki lokus penelitian. Sedangkan penelitian yang dilakukan penulis ini berusaha menggali informasi langsung dari narasumber tentang bagaimana implementasi metode uswah atau suri teladan di masa PJJ pandemi COVID-19 ini.

Dalam pembelajaran pada masa PJJ, Inovasi pembelajaran yang dilakukan oleh pendidik dan seluruh komponen sekolah menjadi salah satu penentu keberhasilan dalam pembelajaran. Pemanfaatan teknologi komunikasi menjadi sebuah keharusan yang tidak bisa dihindarkan. Guru dituntut untuk biasa mengeksplorasi semua unsur di sekitarnya secara maksimal agar proses pembelajaran tetap hidup. Hamalik mengatakan bahwa pembelajaran merupakan suatu kombinasi yang tersusun meliputi unsur-unsur manusiawi, material, fasilitas, perlengkapan, dan prosedur yang saling memengaruhi dalam mencapai tujuan pembelajaran. Material meliputi buku-buku, papan tulis, kapur; fotografi, slide dan film, audio dan video tape. Fasilitas dan perlengkapan terdiri dari ruangan kelas, perlengkapan audio visual, serta komputer. Prosedur meliputi jadwal dan metode penyampaian informasi, praktik, belajar, ujian, dan sebagainya (Hamalik, 2003).

Oleh karena itu, penulis tertarik dan tergugah untuk meneliti dan menganalisis mengenai bagaimana Implementasi Metode uswah hasanah di masa PJJ Pandemi COVID19. Sehingga memungkinkan ditemukan strategi yang tepat dalam penerapannya dan memberikan kontribusi pada dunia pendidikan. Karena keterbatasan mengingat kondisi pandemi ini, metode yang digunakan dalam penelitian ini pun menjadi terbatas. Adapun teknik pengumpulan data hanya melalui wawancara secara daring tanpa melakukan observasi pembelajaran secara tatap muka di sekolah. Namun penggalian informasi dari berbagai sumber tetap dilakukan secara maksimal.

\section{Metode Penelitian}

Penelitian kualitatif dengan metode deskriptif analitik peneliti gunakan untuk mengetahui bagaimana implementasi metode uswah hasanah pada masa Pembelajaran Jarak Jauh (PJJ) Pandemi COVID-19 di MTs Al Azhar Tembongraja, Salem, Brebes, Jawa Tengah. MTs Al Azhar berlokasi di Jalan Raya Tamansari Desa Tembongraja Kec. Salem Kab. Brebes Jawa Tengah. Sekolah swasta ini berdiri sejak 16 Juli 2012 dengan SK 16 Juli 2012 dan kini dikepalai oleh Drs. Risnandar. Visi Madrasah "Unggul dalam Prestasi, Pelopor dalam Iptek dan Imtak, Teladan dalam Bersikap dan Bertindak". Misi Madrasah: mewujudkan peningkatan kualitas tamatan, membentuk generasi cerdas, terampil, kreatif, berdedikasi dan cinta almamater, membentuk generasi yang bertakwa, mandiri, memiliki sikap gotong royong, hormat dan santun kepada kedua orang tua, guru dan masyarakat serta cinta tanah air. 
Implementasi Metode Uswah Hasanah pada Pembelajaran Jarak Jauh...

Data yang dikumpulkan bukan berupa angka-angka, melainkan data tersebut berasal dari hasil wawancara, dokumen pribadi, catatan memo, dan dokumen resmi sekolah. Sumber data primer dalam penelitian ini ialah kepala sekolah, wakil kepala sekolah (waka) kurikulum, wakil kepala sekolah (waka) kesiswaan, sebagian guru, sebagian peserta didik dan sebagian orang tua peserta didik yang dipilih secara acak. Sedangkan sumber data sekunder diambil dari data penunjang seperti jurnal, buku, laporan tahunan dan dokumen lain yang berkaitan dengan masalah penelitian. Data dari para responden dikumpulkan melalui wawancara dan studi dokumentasi.

Teknik analisis data dilakukan sejak pengumpulan data dan dikerjakan secara intensif. Data yang diperoleh dari responden dianalisis melalui pengumpulan data, reduksi data, penyajian data dan penarikan kesimpulan. Uji keabsahan data dilakukan melalui uji credibility (validitas internal) dan triangulasi. Triangulasi data dilakukan dengan membandingkan jawaban informan utama dengan informan pendukung untuk mendapatkan data yang cocok dan sesuai. Triangulasi teknik pengumpulan data dilakukan dengan cara wawancara mendalam dan dokumentasi untuk sumber data yang sama secara serempak. Triangulasi sumber juga dilakukan untuk mendapatkan data dari sumber yang berbeda-beda dengan teknik yang sama.

\section{Hasil dan Pembahasan}

\section{A. Temuan penelitian}

MTs Al Azhar Tembongraja sebagai lembaga pendidikan, merupakan wadah tempat proses pendidikan dilakukan. Selain pendidikan formal juga ada pendidikan moral yang diberikan dengan memberi contoh yang baik. Dalam kenyataannya, guru dipandang sebagai suatu organisasi yang bisa memberikan contoh yang baik bagi anak didiknya. Ketika guru bertemu dengan guru lainnya selalu tersenyum, mengucap salam dan terkadang berjabat tangan, juga ketika guru bertemu dengan kepala madrasah, guru menundukkan kepala sebagai rasa tunduk dan menghormati kepala madrasah.

Tujuan dari penelitian ini ialah untuk mendapatkan informasi mengenai implementasi metode uswah hasanah pada masa PJJ pandemik COVID-19. Semua tanggapan dikutip sebagaimana dinyatakan oleh para responden. Setelah melakukan wawancara dengan narasumber melalui media sosial WhatsApp, diperoleh beberapa pernyataan yang disampaikan oleh para responden sebagai berikut:

Responden ER memberikan tanggapan tentang implementasi metode uswah hasanah pada masa PJJ dengan menyatakan,

Meskipun pada masa PJJ guru tidak bisa bertemu langsung dengan para siswa, metode uswah hasanah atau metode keteladanan tetap bisa di lakukan lewat media sosial meski hasilnya tidak bisa semaksimal seperti pada pembelajaran tatap muka misalnya dengan cara mengucapkan salam setiap akan memberikan tugas atau 
memberikan materi.

Pernyataan yang diberikan DS pun tidak berbeda jauh dengan pernyataan di atas yang menyatakan,

Media WA juga bisa digunakan dalam menerapkan metode uswah, misalnya dengan memberi contoh penggunaan kata-kata yang baik lewat tulisan yang tidak jauh berbeda dengan mengucapkan kata-kata yang baik secara langsung.

Pernyataan-pernyataan di atas bisa dipahami bahwa keterbatasan-keterbatasan yang disebabkan karena adanya peraturan learn from home (LFH) bukan menjadi alasan atau penghambat penyampaian materi atau memberikan contoh yang baik kepada para peserta didik, namun kondisi seperti ini harus bisa dimanfaatkan sebisa mungkin dengan menyesuaikan diri dengan situasi dan kondisi yang ada. Kemajuan teknologi harus bisa dimanfaatkan agar pembelajaran dapat tersampaikan dan peserta didik masih dapat belajar meski hanya dari rumah. Apa yang disampaikan lewat tulisan bisa menjadi alternatif ketika ucapan dan perbuatan tidak bisa dilakukan secara langsung melalui pembelajaran tatap muka.

Kemudian JAR memberikan tanggapannya mengenai penerapan metode uswah hasanah melalui media sosial dengan mengatakan,

Berkomunikasi di media sosial memang memiliki banyak keterbatasan, tetapi berusaha memberikan contoh yang baik kepada anak dengan cara menanyakan kabar dan mendoakan selalu ada dalam lindungan Allah sebagai sikap kepedulian kepada siswa dan itu diikuti oleh para siswa dengan mendoakan teman-teman yang lainnya ketika ada yang sakit.

Sementara LH mengeluhkan sulitnya menerapkan metode uswah hasanah pada masa PJJ dengan menyatakan,

Saya dan para guru yang lain mengalami kesulitan dalam menerapkan metode uswah pada masa COVID-19 seperti sekarang ini, kondisi pedesaan seperti ini memiliki banyak kendala seperti sinyal yang tidak stabil dan ada sebagian siswa yang tidak memiliki handphone android sendiri, tetapi kami berusaha memberikan contoh dengan mengucapkan salam dan memberikan tugas atau materi secara tepat waktu dalam setiap jadwal pelajaran.

Sedangkan AN memberikan tanggapannya dengan menjawab,

Dalam memberikan contoh yang baik kepada anak-anak, saya memberikan reward dengan mengucapkan terima kasih kepada murid yang menyerahkan tugas tepat waktu dan mengucapkan selamat kepada murid yang berprestasi dan kata-kata motivasi lain sebagai bentuk apresiasi untuk menumbuhkan rasa sikap menghargai dan menumbuhkan rasa semangat para siswa.

Berdasarkan tanggapan-tanggapan responden di atas dapat dipahami bahwa adanya kesulitan-kesulitan dalam menerapkan metode uswah pada masa PJJ ini tetap tidak 
Implementasi Metode Uswah Hasanah pada Pembelajaran Jarak Jauh...

menghalangi para pendidik untuk menerapkan metode uswah hasanah meski terbatas hanya dalam jaringan atau dunia maya.

Selanjutnya, ER menyampaikan terkait uswah hasanah yang biasa dilakukan sebelum masa PJJ dan uswah hasanah yang masih bisa dilakukan di masa PJJ dan tidak bisa dilakukan dengan mengatakan,

Para guru dan komponen sekolah biasa memberikan teladan atau uswah hasanah di antaranya dengan berjabat tangan, mengucapkan salam, masuk kelas tepat waktu, berpakaian rapi, bertutur kata yang sopan dan lembut, memungut sampah dan membuangnya ke tempat sampah dan banyak lagi yang lainnya. Namun setelah masa PJJ, uswah hasanah yang bisa dan masih bisa diusahakan tetap dilaksanakan melalui media sosial, kecuali ada beberapa yang sulit dilakukan seperti berjabat tangan, memungut sampah, berpakaian rapi, bertutur kata dengan suara yang lembut dan lain-lain.

Dari pernyataan di atas dapat dipahami bahwa ada beberapa teladan atau uswah hasanah yang sulit atau tidak bisa dilakukan melalui media sosial. Berikut tabel uswah hasanah yang bisa dilaksanakan dan tidak bisa dilaksanakan pada masa PJJ di MTs Al Azhar Tembongraja Salem

Tabel 1. Tabel Uswah Hasanah

\begin{tabular}{clcc}
\hline No. & \multicolumn{1}{c}{ Uswah hasanah (Teladan) } & $\begin{array}{c}\text { Bisa dilaksanakan } \\
\text { pada masa PJJ }\end{array}$ & $\begin{array}{c}\text { Tidak bisa dilaksanakan } \\
\text { pada masa PJJ }\end{array}$ \\
\hline 1. & Jabat tangan & $\sqrt{ }$ & \\
2. & Salam & & $\sqrt{ }$ \\
3. & Masuk kelas tepat waktu & & $\sqrt{ }$ \\
4. & Berpakaian rapi & & $\sqrt{ }$ \\
5. & Tutur kata dengan suara lembut & $\sqrt{ }$ & \\
6. & Membuang sampah pada tempatnya & $\sqrt{ }$ & \\
7. & Bertutur yang baik lewat tulisan & $\sqrt{ }$ & \\
8. & Tolong menolong & $\sqrt{ }$ \\
9. & Mengapresiasi & & \\
10 & Memulai pelajaran tepat waktu & & \\
\hline
\end{tabular}

\section{B. Pembahasan}

Guru memiliki peran penting dalam mendidik siswanya agar terlahir siswa yang berilmu, berprestasi, dan berakhlak yang baik. Dalam metode keteladanan, guru sebagai figur harus menjadi contoh yang baik untuk siswanya ketika di sekolah maupun di luar sekolah karena apa pun yang dilakukan guru akan ditiru dan dianalisis oleh siswa. Metode merupakan cara yang teratur dan terpikir baik-biak untuk mencapai suatu maksud (Sudjana S., 2010). Ahmad Tafsir mengungkapkan bahwa metode ialah istilah yang digunakan untuk mengungkapkan pengertian cara yang paling tepat dan cepat dalam melakukan sesuatu. Lebih lanjut beliau menjelaskan bahwa ungkapan paling tepat dan cepat itulah yang membedakan method dengan way (yang juga berarti cara) dalam bahasa Inggris (Tafsir, 1996). 
Dari uraian di atas dapat dipahami bahwa metode merupakan cara yang tersusun secara sistematis untuk mencapai sebuah tujuan. Metode juga bisa diartikan sebagai cara mengerjakan sesuatu yang mungkin baik dan mungkin juga tidak baik. Baik dan tidak baiknya sesuatu metode tergantung pada beberapa faktor. Faktor-faktor tersebut berupa situasi dan kondisi dalam penggunaan metode tersebut. Dalam kaitannya dengan pembelajaran, dapat dipahami bahwa metode merupakan suatu cara agar tujuan pembelajaran tercapai sesuai dengan tujuan yang telah dirumuskan oleh pendidik.

Dalam al-Quran term teladan atau uswah hasanah disebut dengan istilah "uswah" dan "Iswah" atau dengan kata "al-qudwah" dan "al qidwah" yang memiliki arti suatu keadaan ketika seseorang manusia mengikuti manusia lain, apakah dalam kebaikan, dan kejelekan (Armai, 2002). Dari pernyataan tersebut bisa dipahami bahwa uswah hasanah merupakan hal-hal yang dicontoh atau ditiru oleh seseorang dari orang lain. Uswah hasanah yang dimaksud ialah keteladanan yang bisa dijadikan sebagai alat pendidikan Islam, yaitu keteladanan yang baik.

Metode uswah hasanah merupakan metode pendidikan dan pengajaran dengan cara memberikan contoh perilaku yang baik yang dapat dijadikan teladan oleh peserta didik untuk diterapkan dalam kehidupannya. Suri teladan dari para pendidik merupakan faktor yang besar pengaruhnya dalam pendidikan. Pendidik terutama orang tua dalam rumah tangga dan guru di sekolah adalah contoh ideal bagi anak atau peserta didik. Salah satu ciri utama anak adalah meniru, sadar atau tidak, akan meneladani segala sikap, tindakan, dan perilaku orang tuanya, baik dalam bentuk perkataan dan perbuatan maupun dalam pemunculan sikap-sikap kejiwaan, serta emosi, sentimen, dan kepekaan (Hapsari, 2016).

Agar tujuan pembelajaran sesuai dengan yang diharapkan, pendidik harus mengetahui, memahami, mempelajari beberapa metode pembelajaran serta dipraktikkan pada saat mengajar. Metode merupakan alat, bukan sebagai tujuan sehingga dalam proses penggunaannya sebuah metode harus sistematis dan kondisional. Maka sesungguhnya penggunaan metode dalam proses belajar mengajar merupakan pelaksanaan sikap hati-hati dalam pekerjaan mendidik dan mengajar. Karena metode berarti cara yang paling tepat dan cepat, maka langkah-langkah dalam suatu metode harus dilakukan dan diperhitungkan benar-benar secara ilmiah. Oleh sebab itu, pada masa PJJ ini, pendidik dan seluruh komponen sekolah di MTs Al Azhar Tembongraja menyesuaikan diri dengan kondisi yang ada dan memanfaatkan media sosial salah satunya sebagai cara untuk menerapkan metode uswah hasanah demi kebaikan dan keselamatan bersama karena jika memaksakan diri melaksanakan pembelajaran secara tatap muka yang justru akan berakibat tidak baik dan mengancam keselamatan orang banyak dan menjadi contoh yang tidak baik bagi peserta didiknya.

Takariawan mengemukakan bahwa faktor penyebab kenakalan anak adalah karena terjadinya krisis prinsip, panutan dan lingkungan (Takariawan, 1972). Pengaruh yang 
Implementasi Metode Uswah Hasanah pada Pembelajaran Jarak Jauh...

paling besar pada pendidikan anak adalah pengaruh dari luar, selain dari bakat alami yang dimiliki tentu faktor dari luar sangat berpengaruh. Untuk mencegah hal itu perlu didikan yang tepat dalam mendidik akhlak atau perilakunya. Penting bagi seorang guru hendaknya tidak hanya mampu memerintahkan atau memberikan teori kepada siswa, tetapi harus mampu menjadi panutan bagi siswanya, sehingga siswa dapat mengikutinya tanpa merasakan adanya unsur paksaan. Oleh karena itu, keteladanan merupakan faktor dominan dan sangat menentukan bagi keberhasilan pendidikan (Maunah, 2007).

Sebelum adanya wabah Corona Virus Diseases tahun 2019 (COVID 19), penerapan metode uswah hasanah di MTS Al Azhar Tembongraja tidak begitu mengalami kendala karena peserta didik mendengar, melihat dan menyaksikan secara langsung hal-hal yang diucapkan dan dilakukan pendidik seperti mengucapkan salam, berjabat tangan, memungut sampah yang berserakan, melaksanakan salat duha bersama, membaca asmaul husna dan membaca al-Qur'an sebelum jam pelajaran pertama dimulai dan lain sebagainya. Namun, setelah World Health Organization (WHO) menyatakan bahwa virus Corona menjadi pandemi di sebagian besar dunia yang berimbas dan mempengaruhi hampir di semua bidang termasuk bidang pendidikan yang kemudian melahirkan peraturan yang mengharuskan penyelenggaraan pendidikan secara jarak jauh atau learn from home (LFH). Sehingga hal tersebut menimbulkan banyak permasalahan dan kesulitan dalam bidang pendidikan, tidak terkecuali pengaruh tersebut berimbas pada lembaga pendidikan MTs Al Azhar Tembongraja, khususnya dalam hal pembentukan akhlak dan karakter yang memerlukan adanya pembiasaan dan peneladanan. Kesulitan dan permasalahan tersebut dikarenakan tidak adanya tatap muka dalam pembelajaran serta kondisi jaringan yang tidak stabil karena lembaga tersebut terletak di pedesaan yang jauh dari kota dan sebagian peserta didik tidak memiliki handphone sendiri.

Demi keberlangsungan hidup manusia yang memiliki peradaban, maka kegiatan pendidikan harus tetap berjalan dalam kondisi apapun. Seperti kebijakan Pembelajaran Jarak Jauh (PJJ) yang dijalani dan dirasakan saat ini. (PJJ) menjadi pilihan sebagai respons atas situasi yang sedang terjadi setelah ada ketetapan oleh Mendikbud guna mengantisipasi penularan COVID-19. Hal tersebut mengacu pada surat edaran Menteri Pendidikan dan Kebudayaan Nomor 36962/MPK/HK/2020 tentang pembelajaran secara daring dan bekerja dari rumah untuk mencegah penyebaran COVID-19. Konsekuensi dari kebijakan tersebut lembaga pendidikan harus mengganti pembelajaran luring dengan daring. Dalam surat edaran tersebut juga, Mendikbud menyarankan adanya pemanfaatan teknologi sebagai alat belajar dan mengajar. Pemanfaatan teknologi tersebut dilakukan karena pembelajaran dilakukan secara jarak jauh. Oleh karna itu, guru atau pendidik hari ini, tidak bisa mengabaikan teknologi dalam proses pembelajaran. Revolusi industri 4.0 telah membawa dampak besar dalam kehidupan khususnya pendidikan (Joenaidy, 2019). 
Kondisi Pandemi memang membuat hampir seluruh bidang memodifikasi sistem yang sudah lama diterapkan saat sebelum pandemi, begitu pula dengan sistem pembelajaran yang dilakukan di MTs Al Azhar Tembongraja. Metode pembelajaran yang biasa dilakukan pun terpaksa harus dimodifikasi demi keberlangsungan pendidikan, begitu pula dengan metode uswah hasanah. Pendidik harus mencari cara untuk mengawal peserta didik dan memberikan contoh yang baik meskipun hanya dalam media sosial. Pendidik di MTs Al-azhar menerapkan metode uswah hasanah di media sosial WhatsApp dengan cara mendahului mengucapkan salam dalam setiap sesi pembelajaran bahkan pada setiap memulai percakapan atau menanyakan kabar peserta didik. Hal ini dilakukan agar peserta didik meneladani ucapan salam tersebut. Meskipun ucapan salam yang ditulis tidak terdengar dan terlihat oleh peserta didik, tetapi pada dasarnya apa yang ditulis dan apa yang diucapkan tidak begitu berbeda dalam hal memberikan pengaruh dan implikasi kepada peserta didik. Nyatanya, hal tersebut ditiru dan diteladani peserta didik ketika akan bertanya kepada guru ataupun peserta didik yang lain.

Selanjutnya, guru MTs Al Azhar Tembongraja juga mencontohkan tepat waktu dalam setiap jadwal pelajaran yang dilakukan di media sosial. Hal ini dilakukan untuk memberikan teladan kedisiplinan bagi peserta didik meskipun ada sebagian peserta didik yang terlambat merespons apa yang di sampaikan dan ditugaskan oleh guru. Hal tersebut bisa katakana wajar mengingat banyak peserta didik yang tinggal di pegunungan yang mengalami banyak kendala terkait jaringan atau karena peserta didik yang terlambat tersebut mengandalkan handphone orang tuanya karena tidak memiliki handphone sendiri. Tetapi setidaknya guru atau pendidik sudah memberikan uswah hasanah tentang pentingnya disiplin agar kehidupan peserta didik ke depan meraih kesuksesan.

Guru MTs Al Azhar Tembongraja juga menyapa, menanyakan kabar peserta didik dan keluarganya serta mendoakan peserta didik. Hal tersebut dilakukan agar peserta didik tetap memiliki sikap peduli meskipun tidak bertemu secara langsung. Kepedulian tersebut penting ditanamkan kepada peserta didik agar mereka tidak bersikap individual dan acuh pada keadaan temannya atau orang lain. Selain itu guru memberikan reward dengan kata selamat bagi siswa yang berprestasi dan memberikan kata-kata motivasi lainnya bagi siswa-siswa lain agar terus berusaha lebih baik. Hal itu dilakukan sebagai bentuk apresiasi dan memberikan semangat kepada peserta didik agar peserta didik mempunyai sikap menghargai dan berbahagia terhadap capaian yang diperoleh temannya atau orang lain dan tetap memiliki semangat untuk memperbaiki kekurangannya serta memiliki sikap optimis.

Apa yang lakukan dan diterapkan oleh pendidik dan semua komponen sekolah di MTs Al Azhar Tembongraja senada dengan apa yang sampaikan oleh Awaludin Faj yang mengatakan bahwa pembelajaran jarak jauh di saat peserta didik sedang school from home (sekolah dari rumah) atau learn from home (belajar dari rumah) dapat tetap 
Implementasi Metode Uswah Hasanah pada Pembelajaran Jarak Jauh...

dikawal dan dikontrol oleh pendidik. Salah satunya dengan memberikan lembar kontrol. Adapun tahapan-tahapan metode keteladanan yang bisa dilakukan di saat pandemi dengan pembelajaran jarak jauh ini adalah: Pembuatan lembar kontrol atau worksheet tentang Akhlak Terpuji \& Tanggung jawab di rumah seperti sifat religius, jujur, disiplin, tanggung jawab, peduli, toleransi, gotong royong, santun, percaya diri dan lain-lain, guru memberikan penilaian dari lembar kontrol yang diberikan, dan guru memberikan umpan balik dalam penguatan karakter dan pembiasaan di dalam rumah. Reward and punishment, guru dapat juga memberikan apresiasi kepada peserta didik yang berprestasi setidaknya dengan mengucapkan kata selamat di grup WA peserta didik. Dalam memberikan hukuman (punishment) guru memperingatkannya melalui jalur WA pribadi (japri) agar nama baiknya tetap terjaga dan anak tidak merasa direndahkan di depan teman-temannya. Akan tetapi jika hal buruk tersebut terus dilakukan berulang, guru boleh menegurnya di grup WA peserta didik secara umum dengan tujuan memberikan pelajaran kepada peserta didik yang lainnya supaya tidak melakukan hal yang demikian. Apabila peserta didik menyelesaikan tugas tepat waktu, guru dapat juga memberikan kata selamat dan menegur peserta didik yang terlambat sebagai hukumannya sebagai bentuk penanaman sikap disiplin. Ketika ada kabar seorang peserta didik tidak dapat mengerjakan tugas karena sakit atau terkendala jaringan, guru dapat mengajak peserta didik untuk mengirimkan pulsa sebagai bentuk penanaman karakter peduli sesama. Wali kelas dan guru-guru lainnya harus tetap selalu mengontrol setiap ucapan atau kata yang ditulis oleh siswa dalam grup WA sebagai bentuk penanaman karakter sopan dan santun dalam berucap dan bertanggung jawab atas semua ucapan dan perbuatan mereka. Pengawasan guru juga harus tetap dilakukan dalam perkembangan pembelajaran peserta didik di rumah dengan terus berkomunikasi dengan orang tua atau keluarganya. Guru harus menumbuhkan kekaguman dan keteladanan orang tua bagi peserta didik di dalam rumah, hal ini bisa melalui dengan kisah dan kewajiban patuh dan taat kepada orang tua. Guru memberikan kepercayaan dan tanggung jawab kepada anak (Faj, 2021).

Ada beberapa uswah hasanah yang biasa dilaksanakan sebelum masa PJJ namun tidak dilaksanakan pada masa PJJ di MTs Al Azhar Tembongraja seperti berjabat tangan, bertutur kata dengan suara yang lembut, memungut sampah dan membuang pada tempatnya serta berpakaian rapi. Dalam hal ini, teknologi yang semakin canggih bisa dan harus dimanfaatkan oleh pendidik agar pembelajaran menjadi lebih hidup. Media Audio atau voice note dapat menjadi alternatif untuk bertutur kata dengan suara yang lembut. Wicaksono mengemukakan hasil penelitiannya bahwa pemanfaatan media audio berupa rekaman dapat meningkatkan kualitas proses pembelajaran (Wicaksono, 2017).

Dalam uswah hasanah membuang sampah pada tempatnya, guru dapat melakukannya dengan cara membuat atau merekam video di rumah atau di halaman tempat tinggalnya ketika memungut sampah dan membuang pada tempatnya. Video 
tersebut dibagikan di grup media sosial peserta didik supaya bisa diteladani di rumah dan di lingkungan sekitar peserta didik masing-masing. Begitu pun uswah hasanah berpakaian rapi dan lain sebagainya yang bisa disampaikan melalui audio visual atau video.

Pemilihan media video memberikan manfaat yang besar dalam penyampaian pesan dalam pembelajaran. Media video merupakan media pembelajaran yang paling tepat dan akurat dalam menyampaikan pesan dan akan sangat membantu pemahaman peserta didik. Dengan adanya media video, peserta didik akan lebih paham dengan materi yang disampaikan pendidik. Unsur-unsur yang terdapat dalam media video seperti suara, teks, animasi, dan grafik. Dengan adanya media video peserta mampu mencapai kemampuan dalam ranah kognitif, afektif, psikomotorik dan meningkatkan kemampuan interpersonal (Yudianto, 2017).

\section{Kesimpulan}

Berdasarkan hasil temuan dalam penelitian yang dilaksanakan di MTs Al Azhar Tembongraja ini ialah bahwa Implementasi metode uswah hasanah dimasa PJJ pandemi COVID 19 ini pendidik mengalami berbagai kesulitan karena hampir tidak adanya tatap muka selama pembelajaran. Namun, pendidik berusaha semaksimal mungkin untuk menerapkan metode uswah hasanah di media sosial WhatsApp dengan cara mendahului mengucapkan salam dalam setiap sesi pembelajaran, tepat waktu dalam setiap jadwal pelajaran, menyapa peserta didik, memberikan reward dan mengapresiasi peserta didik dengan kata selamat dan kata-kata motivasi lainnya bagi siswa yang berprestasi melalui grup media sosial dan lain sebagainya. Pemanfaatan audio (voice note) dan video (audio visual) menjadi hal yang sangat penting dalam uswah hasanah pada masa PJJ agar pendidikan dan pembelajaran yang dilaksanakan dapat menjadi lebih hidup. Oleh sebab itu, guru dituntut untuk bisa mengeksplorasi semua unsur termasuk unsur fasilitas dan perlengkapan yang di dalamnya memerlukan kecakapan dalam menggunakan dan memanfaatkan teknologi dalam pembelajaran.

\section{Daftar Pustaka}

Armai, A. (2002). Pengantar Ilmu dan Metodologi Pendidikan Islam. Jakarta: Ciputat Press. Faj, A. (2021). PENERAPAN METODE PEMBELAJARAN SURI TAULADAN DI ERA PANDEMI. Ta'lim, 03(1), 39-57.

Hamalik, O. (2003). Kurikulum dan Pembelajaran. Jakarta: Bumi Aksara.

Hapsari, W. (2016). Widyaning Hapsari, Model Pendidikan Karakter pada AUD Melalui Program Islamic Habituation, Jurnal Indigenous, Vol. 1 No. 2 (2016), h. 25. Jurnal Indigenous, 1(2).

Hidayatul, K. (2016). Metode Bimbingan dan Konseling Islam dalam Menanamkan Kedisiplinan Sholat Duha pada anak MI Nurul Islam Ngalian Semarang. Jurnal Ilmu Dakwah, 36(1).

Joenaidy, A. M. (2019). Konsep dan Strategi Pembelajaran di Era Revolusi Industri 4.0. 
Implementasi Metode Uswah Hasanah pada Pembelajaran Jarak Jauh...

Yogyakarta: Laksana.

Ma'awiyah, A. (2017). METODE USWAH HASANAH DALAM PEMBENTUK KARAKTER USIA MI/SD. IDĀRĀH Jurnal Pendidikan dan Kependidikan, 1(1), 16.

Machsunah, \& Chayatun, Y. (2017). Penanaman Pendidikan Karakter Melalui Keteladanan Pendidik (Studi Kasus Di Lbb Taman Pintar: Sahabat Sekolah Anak Lamongan). Journal Stkip Pgri Lamongan, 1(2).

Maesaroh, S., Abdussalam, A., \& Surahman, C. (2019). EFEKTIVITAS METODE USWAH HASANAH DALAM PROSES PEMBELAJARAN PAI (Studi Eksperimen di SMPN 29 Bandung). TARBAWY: Indonesian Journal of Islamic Education, 5(2), 123. https://doi.org/10.17509/t.v5i2.16737

Maunah, B. (2007). Materi Penyusunan Desain Pembelajaran Akidah Akhlak. Jember: Indonesia.

McCall, J. (2004). Distance Learning. Http://Www.Gsu.Edu/Mstsh/Course/It7000/Papers/ Distance3.Htm.

Patoni, A. (2004). Metodologi Pendidikan. Jakarta: Bina Ilmu.

Purwanto. (2009). 30 Tahun Kiprah Pustekkom dalam Pendidikan. Jakarta: Pusat Teknologi Komunikasi dan Informasi Pendidikan-Departemen Pendidikan Nasional.

Rosyadi, K. (2014). Pendidikan Profetik. Yogyakarta: Pustaka Pelajar.

Ruzgar, N. S. (2004). Distance Education in Turkey. Turkish Online Journal of Distance Education, 5(2), 22-32. https://doi.org/10.4018/978-1-60566-198-8.ch095

Sudjana S. (2010). Metode dan Tehnik Pembelajaran Partisipatif. Bandung: Falah Prodution.

Tafsir, A. (1996). Metodologi pengajaran Agama Islam,. Bandung: PT. Remaja Rosdakarya. Takariawan, C. (1972). Pernik-pernik Rumah Tangga Islam. Jakarta: Bulan Bintang.

Wicaksono, A. (2017). Peran Media Audio dalam Meningkatkan Kualitas Proses Pembelajaran Apresiasi Cerita Pendek. SHAHIH: Journal of Islamicate Multidisciplinary, 2(1), 67. https://doi.org/10.22515/shahih.v2i1.670

Yudianto, A. (2017). PENERAPAN VIDEO SEBAGAI MEDIA PEMBELAJARAN. Seminar Nasional Pendidikan. 